\title{
Serebral palside kalça sorunları
}

\author{
Hip problems in cerebral palsy
}

\author{
Serkan Erkuş, Önder Kalenderer
}

İzmir Tepecik Eğitim ve Araştırma Hastanesi, Ortopedi ve Travmatoloji, İzmir

\begin{abstract}
Serebral palside kalça sorunları oldukça önemlidir. Genelde 2-8 yaş arası görülür. Spastik kuadri-paretik ve kaba motor fonksiyon skalasına göre geri olan hastalar risk altındadır. Adduksiyon ve/veya fleksiyon kontraktürü en hafif formudur. Genelde femur anteversiyon açıları artmıştır. Subluksasyon ve çıkık görülebilir. Kalça grafilerinde migrasyon indeksinin ölçülmesi ve hastaların bu değere göre izlenmesi gerekir. Yumuşak doku gevşetme ameliyatları, femoral veya asetabular osteotomiler, tek tek ya da kombine olarak uygulanabilir. Ancak en önemlisi, spastik hastalarda kalça sorunlarının çoğunun önlenebilir olmasıdır.
\end{abstract}

Anahtar sözcükler: serebral palsi; spastisite; kalça; paralitik çıkık

\section{ANATOMI VE BIYOMEKANIK}

Kalça eklemi klasik bir top ve yuva tipi eklemdir. ${ }^{[1]}$

Asetabulum ilium, iskium ve pubisin birleşmesiyle oluşan kavite şeklinde bir yapıdır. Asetabulumda bu üç kemiğin birleşmesi 14-16 yaşları arasında başlar ve 23 yaşında son bulur. ${ }^{[2]}$ Asetabulum, hiyalin kıkırdak ile kaplıdır ve bu kıkırdağın en kalın olduğu yer superior bölümüdür. Normalde asetabulum $20-40^{\circ}$ arası anteverttir ve asetabular inklinasyon $20-40^{\circ}$ arasıdır. ${ }^{[3]}$

Femur başının çapı $45-56 \mathrm{~mm}$ arasında ve küre şeklindedir. Bunun \%60-70'i kıkırdak ile hiyalin kaplıdır. Femur başı ile cismi arasında femur boynu vardır. Femur boynu ile femur cismi arasındaki açı kollodiyafizer açıdır ve normali $125 \pm 5^{\circ}$ 'dir. Femur boynu ile transkondiler aks arası açı ise femoral anteversiyon açısıdır. Doğumda $30-40^{\circ}$ öne doğru olan bu açı, yaşla azalarak erişkinlerde $15-20^{\circ}$ arasına iner. Bazı bireylerde ise arkaya dönük (retrovert) olabilir.
Hip problems are very important in cerebral palsy. They are usually diagnosed between ages 2 and 8. Spastic quadriparetic patients, and those with backward comorbidity according to the rough motor function scale are at risk. The lightest form is adduction and/or flexion contracture. In gen-eral, the femoral anteversion angles of these patients increase. Subluxation and dislocation can be observed. Migration index should be measured on the hip radiographs, and patients monitored according to this value. Soft tissue releasing operations, and femoral or acetabular osteotomies can be performed individually or in combination. However, most important point is that most of the hip problems can be avoided in spastic patients.

Key words: cerebral palsy; spasticity; hip; paralytic luxation

- İletişim adresi: Doç. Dr. Önder Kalenderer, İzmir Tepecik Eğitim ve Araştırma Hastanesi, Güney Mah. Gaziler Cad. No: 468 Konak, İzmir Tel: 0532 - 2971067 e-posta: okalenderer@gmail.com

- Geliş tarihi: 1 Ekim $2018 \quad$ Kabul tarihi: 1 Ekim 2018

Kalça ekleminin ana fleksörü iliopsoas kasıdır. Sartorius, rektus femoris, pectineus ve tensor fasya lata da fleksiyona yardımcı olur. En güçlü ekstansörü gluteus maksimus kasıdır. Ana abduktoru ise gluteus medius ve minimustur. İç rotator kasları; tensor fasya lata, gluteus mediusun ön yüzü ve gluteus minimus, dış rotatorları ise; obturator internus, obturator eksternus, gemellus superior, gemellus inferior, piriformis ve kuadratus femoristir.

Kalça ekleminde normalde; sagittal planda 120$130^{\circ}$ fleksiyon, $10-15^{\circ}$ ekstansiyon hareketi yapılır. ${ }^{[4]}$ Kalça ekstansiyonda iken iç ve dış rotasyon hareketleri fleksiyonda olduğuna göre daha sınırlıdır.

Kalça eklemine, yerçekimi kuvveti (vücut ağırlığı), abduktor kol kuvveti ve eklem reaksiyon kuvveti etkimektedir. Abduktor kol kuvveti, tek ayak üzerinde iken pelvisi yere paralel olarak tutacak kadar güçte olmalıdır. Eğer abduktor kas grubu yerçekimi kuvvetine karşı 
koyamazsa, pelvis yere paralel olarak duramaz, kalça eklem reaksiyon gücü azalır ve "Trendelenburg bulgusu ve topallaması" denilen durum ortaya çıkar. ${ }^{[5]}$

\section{GENEL BILGILER}

Serebral palsi (SP) hastalarında kalça problemleri ciddi ve sık karşılaşılan bir durumdur. SP'ye bağlı kalça sorunları sıklığı, \%2-75 oranlarında bildirilmektedir. Bunlar, basit bir spastisite veya adduksiyon kontraktüründen paralitik yüksekte kalça çıkı̆̆ına kadar geniş bir yelpazede karşımıza çıkabilir. Spastisiteye bağlı oluşan kalça sorunları, gelişimsel kalça displazisinden (GKD) oldukça farklıdır. SP'de, doğumda kalça genelde normaldir. Kalça sorunları zaman içinde, kas kontraktürlerine veya skolyoz gibi diğer deformitelere sekonder olarak gelişir. SP'li hastanın nörolojik tutulum düzeyi, paralitik kalça çıkığı oluşmasında en etkili faktörlerden biridir. Bağımsız yürüyebilen SP'li hastalarda kalça lateralizasyonu ve paralitik kalça çıkığı oranları \%7’lerde bildirilirken, yatağa bağlı kuadriparetik olgularda bu oran \%60'lara kadar çıkmaktadır. ${ }^{[6,7]}$ Spastik hemiparetik olgularda neredeyse hiç kalça sorunu görülmezken, kuadriparetik olgularda çok sık görülmektedir. Yine, pür ataksik çocuklarda da kalça sorunları çok olmamaktadır. ${ }^{7]}$ Yürümenin gecikmesi de, kalça sorunları ile karşılaşma şansını arttıran bir diğer etkendir. Üç yaşına kadar yürüyemeyen olgularda paralitik kalça çıkığı görülme riski daha fazladır. ${ }^{[8]}$ Yukarıda da belirtildiği gibi, skolyoz gibi suprapelvik nedenler pelvik obliklik yaratarak paralitik kalça çıkığına yol açabilir. ${ }^{[6]}$

\section{SP'de Kalça Sorunları}

\section{Adduksiyon kontraktürü (Şekil 1)}

2. Fleksiyon-adduksiyon kontraktürü

3. Artmış femoral anteversiyon açısı ve coxa valga (Şekil 2)

4. Subluksasyon (Şekil 3)

5. Paralitik kalça çıkığı (Şekil 4)

\section{PARALITIK KALÇA ÇIKIĞI OLUŞMA MEKANIZMASI}

SP'li çocukların çoğunda kalça doğumda normaldir. Asetabular displazi ya da femur başı hipoplazisi yoktur. Özellikle iliopsoas, adduktorlar ve iç rotatorların kontraktürü normal kalça gelişimi olan SP'li hastada zaman içinde sorun yaşanmasına neden olur. Fizik tedavisi uygun yapılmayan veya uyum sorunu yaşayan hastalarda, bacakların fleksiyon adduksiyon ve iç rotasyonu zamanla kalçalarda lateralizasyona, subluksasyona ve hatta ciddi paralitik çıkıklara neden olabilir.

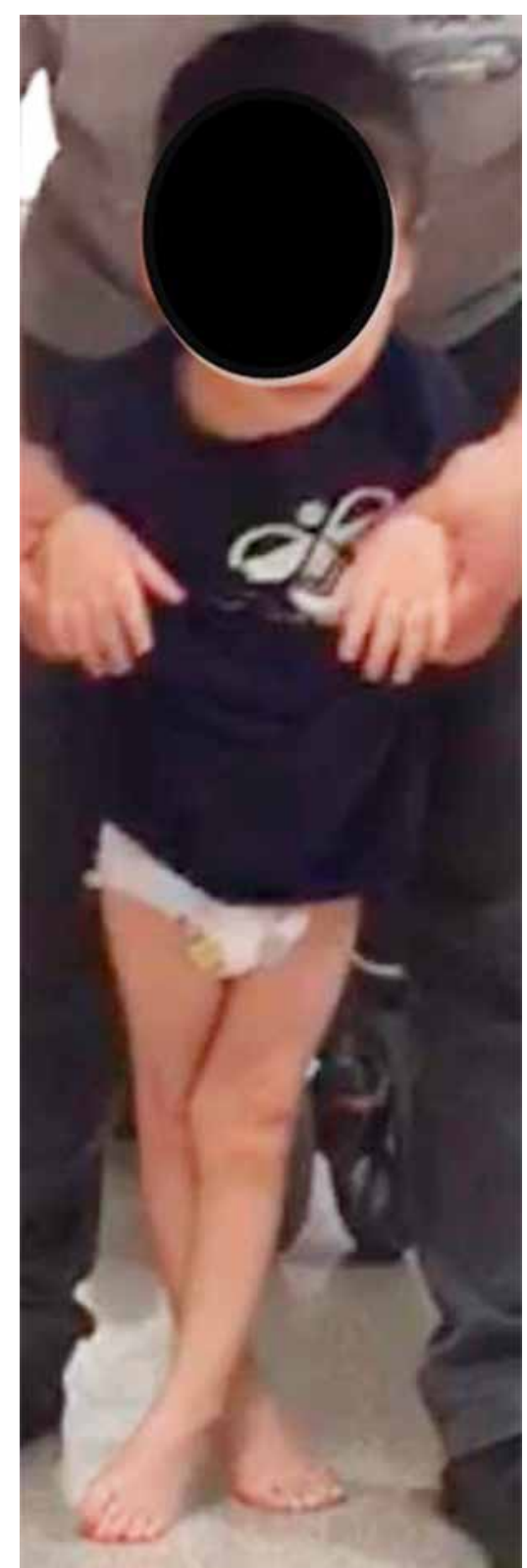

Şekil 1. Adduksiyon kontraktürü.

Kas kontraktürleri yumuşak doku dişında femur proksimal bölgesini de kötü yönde etkiler ve coxa valga deformitesi ve femoral anteversiyon açısında artışa neden olur. ${ }^{[6]}$ Bu kemiksel deformitelerin oluşmasında, elbette yürümede gecikme de en önemli etkenlerden biridir. GKD'den farklı olarak, paralitik çıkıklar kas kontraksiyonlarına ve hastanın pozisyonuna bağlı oluştuğundan, çıkık posteriora doğru olmakta ve asetabulumun posteriorunda yetmezlik oluşmaktadır. Basıya bağlı femur başında erozyon, deformite ve zamanla artroz bulguları ortaya çıkar. 


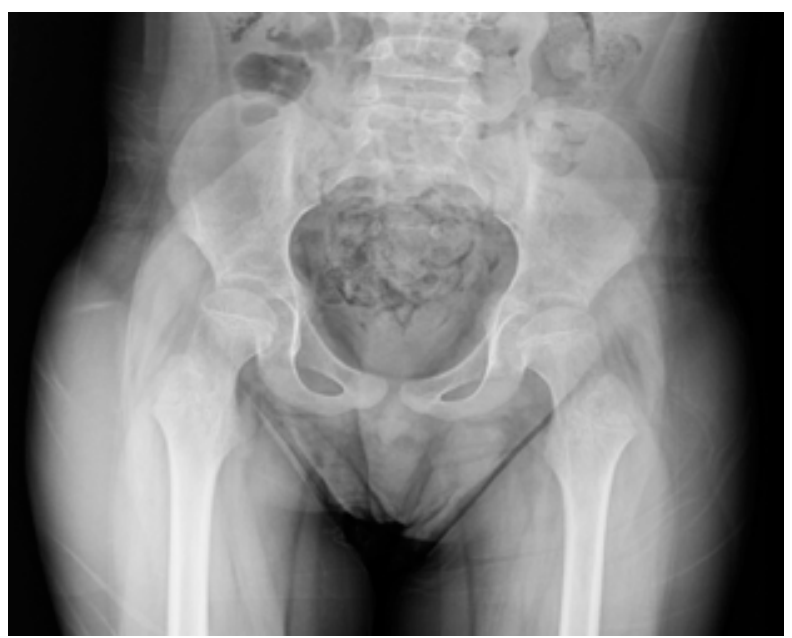

Şekil 2. Altı yaşındaki hastada boyun-cisim açısında artma (coxa valga).

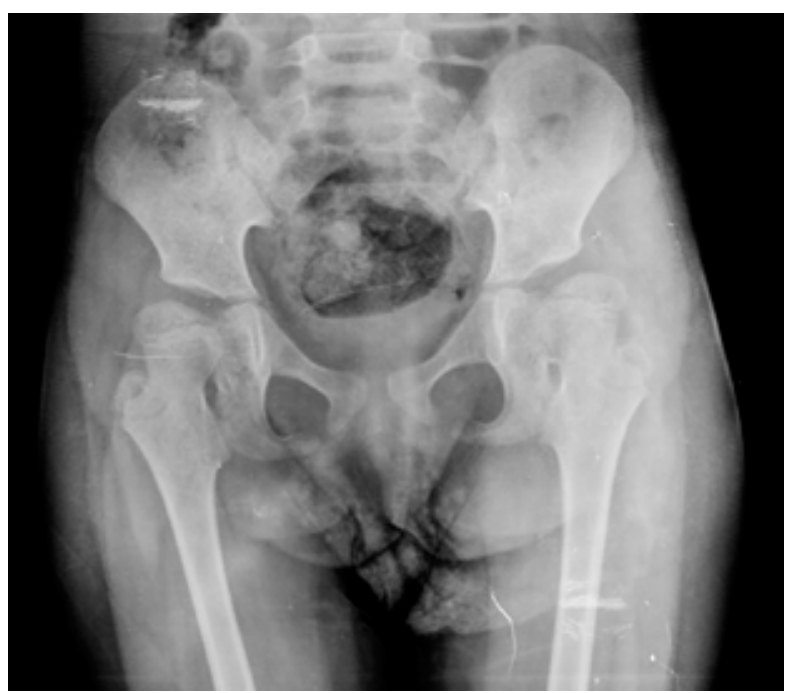

Şekil 3. Kuadriparetik spastik hastada iki taraflı adduksiyon kontraktürü ve subluksasyon. Migrasyon indeksi: $\% 65$.

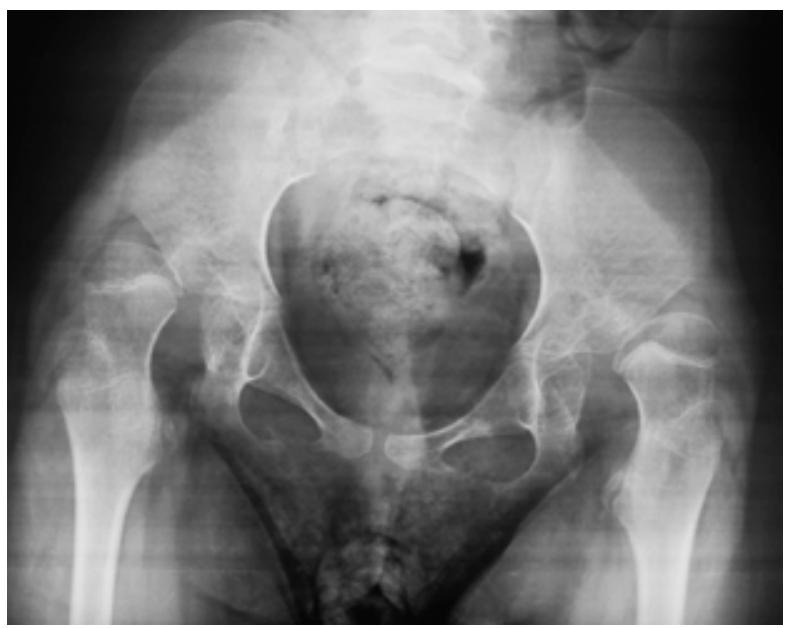

Şekil 4. İki taraflı paralitik kalça çıkığı.

\section{Paralitik Kalça Çıkığı Nedenleri}

1. Yürüyememe ya da geç yürüme

2. Ağır nörolojik tutulum

3. Beyindeki hasarın yerleşim yeri

4. Skolyoz

5. Ağır kontraktürler (windswept)

\section{FiZiK MUAYENE}

SP'li hastalarda sistemik muayene yapılması belki de tüm hastalıklardan daha önemlidir. Hasta bir bütün olarak değerlendirilmelidir. Tüm muayene bulguları kayıt altına alınmalıdır, hastanın durumu ve hastalığının ilerleyişi mutlaka izlenmelidir.

SP'li hastada kalça abduksiyon ve fleksiyon muayenesi oldukça önemlidir. Kalça fleksiyon kontraktürü "Thomas testi" ile değerlendirilir. Muayene masasında sırt üstü yatan hastanın, dizler fleksiyonda iken her iki kalçası fleksiyona getirilir. Burada pelvisin anteriora tilti olmadan önceki kalça fleksiyonu yeterlidir. Aşırı fleksiyon yanıltıcı olabilir. Bu sırada lomber lordozun düzleşmiş olması da önemlidir. Ardından, muayene edilen tarafın kalça ve dizi ektansiyona getirilir. Diz tam ekstansiyonda iken kalçanın yer düzlemi ile olan açısı, kalçadaki fleksiyon kontraktürünü verir. ${ }^{\left[{ }^{9]}\right.}$ Kalça abduksiyon açıklığı, hasta sırt üstü yatarken diz ve kalçalar hem fleksiyonda hem de ekstansiyonda muayene edilmelidir. Kalçadaki adduksiyon kontraktürünün derecesi, kalça sorunlarının büyümesinde en büyük etken olarak karşımıza çıkmaktadır. SP'li hastaların periyodik muayeneleri bu yüzden önem taşır. Bacaklarda çaprazlaması olan olgularda ve ilk kez gelen tüm SP'li hastalarda ön-arka planda kalça grafisi çekilmelidir. Ayrıca, adduksiyon kontraktüründeki artış, spastik kuadriparetik hasta, mental retardasyon, skolyoz, pelvik tilt, ciddi kontraktürleri olan hasta, uyumsuz aile ile fizik tedavi ve rehabilitasyona uyum sorunlarının olduğu durumlarda daha da dikkatli olunmalıdır.

Kalçada bir diğer sorun da femur anteversiyon açısının artmasıdır. Yüzükoyun yatan hastada Craig yöntemi ile femoral anteversiyon açısı belirlenmelidir (Şekil 5). Kalça adduksiyon kontraktürünün ilerlemesiyle birlikte kalça çıkık haline gelirse, kalça hareketlerinde kısıtlılık, bacakta kısalık ve pelvik obliklikte bozulma olur. Zamanla, özellikle perianal temizlik zorlu ve ağrılı hale gelir.

\section{RADYOLOJiK DEĞERLENDIRME}

SP'li hastalarda belki de en önemli sorun kalçaya ait olanlardır. Özellikle paralitik kalça çıkığının geliştiği durumlarda, tedavi şekli değişmekte ve büyümektedir. 


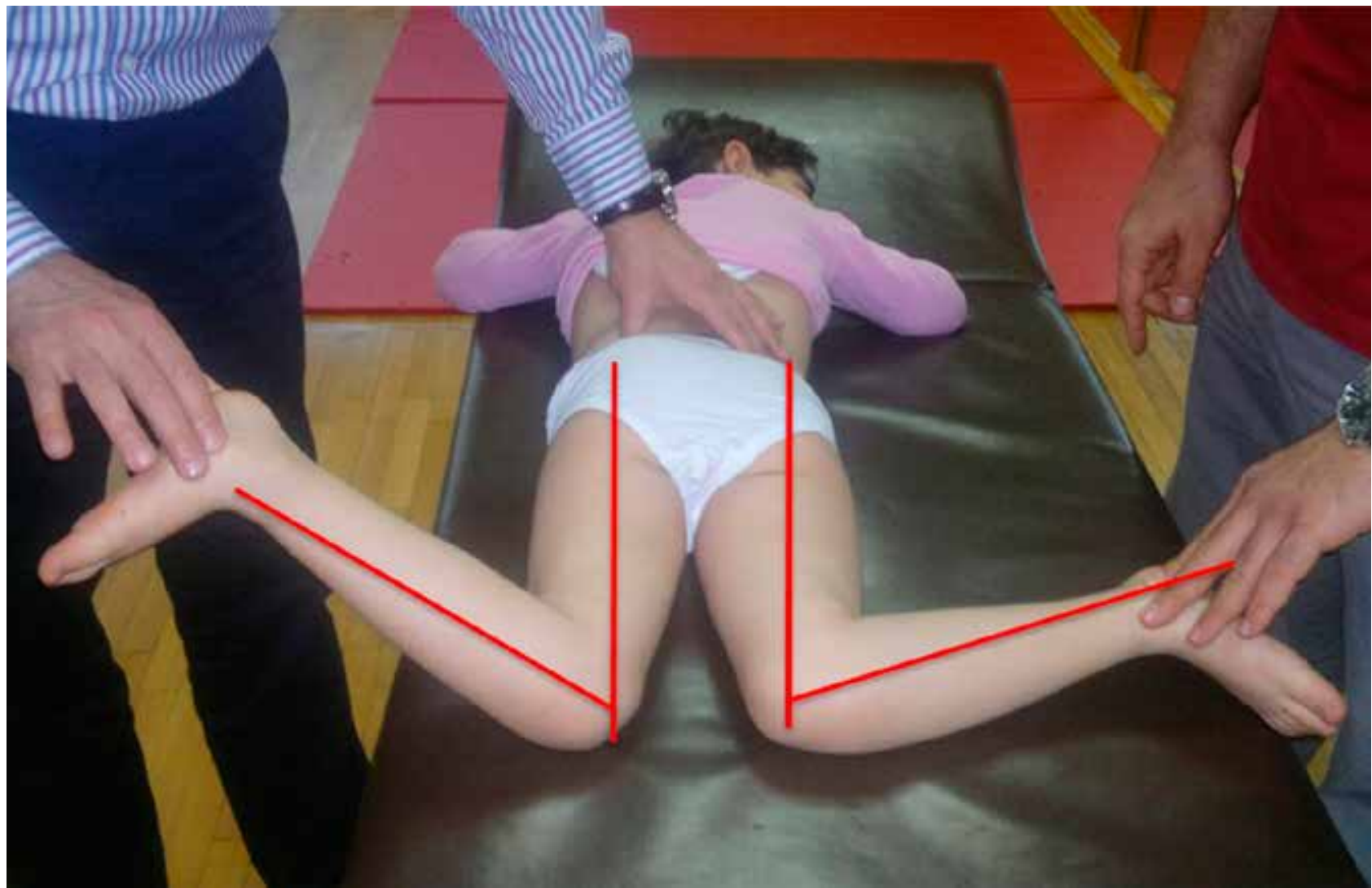

Şekil 5. Craig yöntemi ile femoral anteversiyon açısının ölçümü.

Bu nedenle, riskli olan, ilk defa muayeneye gelen ve şüphe duyulan hastaların kalça ön-arka grafisi istenmelidir. Kalça grafisi olabildiğince standarda yakın çekilmelidir. Kalça grafisi üzerinde asetabular indeks açısı (Ai) ve migrasyon indeksi (Mi) ölçülmelidir.

Ai genelde GKD olan olgularda normalden yüksektir. Paralitik çıkık olgularında normal değerlerdedir ve rutinde izlem amaçlı çok da kullanılmamaktadır. Ancak, literatürde Ai'nin spastik kalça hastalarının izleminde birincil düzeyde önemli olduğunu bildiren çalışmalar da bulunmaktadır. ${ }^{[10]}$

Mi, her iki $Y$ kıkırdağını birleştiren Hilgenreiner çizgisi üzerinde, femur başının asetabulum üst dış köşesinden taşan kısmının femur başı çapına oranıdır (Şekil 6). Mi en fazla \%25 olmalıdır. Mi, spastik hastaların kalça sorunlarının izlenmesinde en önemli göstergedir ve rutinde çok kullanılır. ${ }^{[7]}$ Mi'nin bir yıl içerisinde \%10'dan az artması, kalça ekleminde bir yıllık süreçte değişimin olmadığını, \%10'dan fazla artması kalça ekleminde çıkığa doğru ilerleyişin olduğunu (Şekil 7), \%10 ve daha fazla düşmesi ise kalça ekleminde subluksasyonun azaldığını gösterir. ${ }^{[7]}$ Kalça

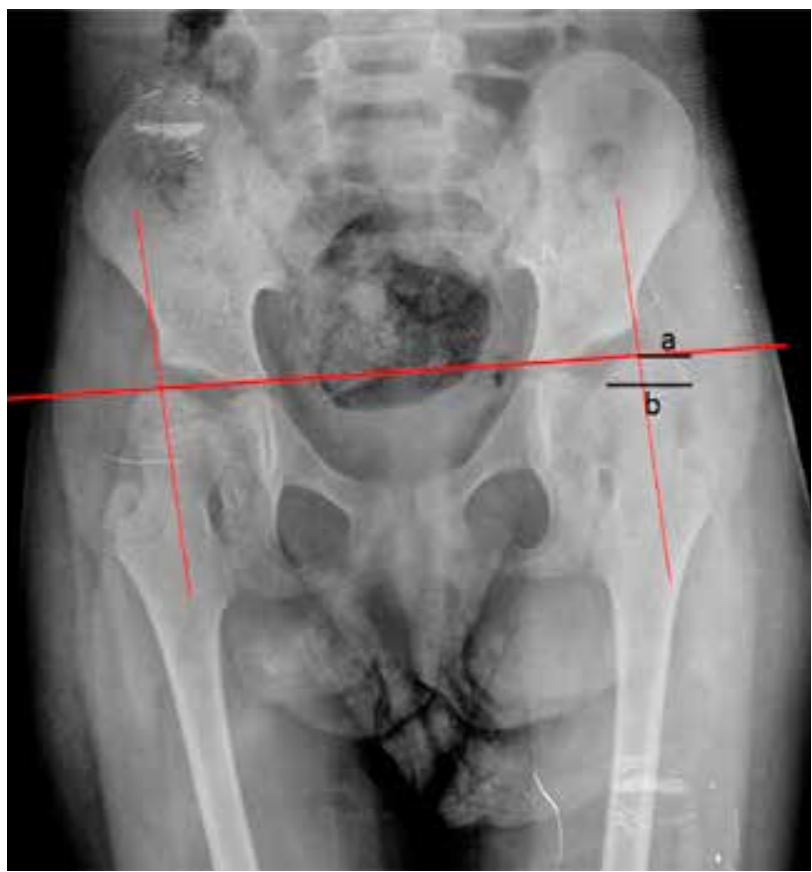

Şekil 6. Migrasyon indeksi (Mi), spastik hastalarda kalçanın çıkıp çıkmadığını izlemede en önemli değerlendirme yöntemidir. Hilgenreiner çizgisine asetabulum üst dış kadranından çizilen dik çizgiyi femur başının ne kadarının çıktığına bakılarak hesaplanır (Mi: \%a/b). 


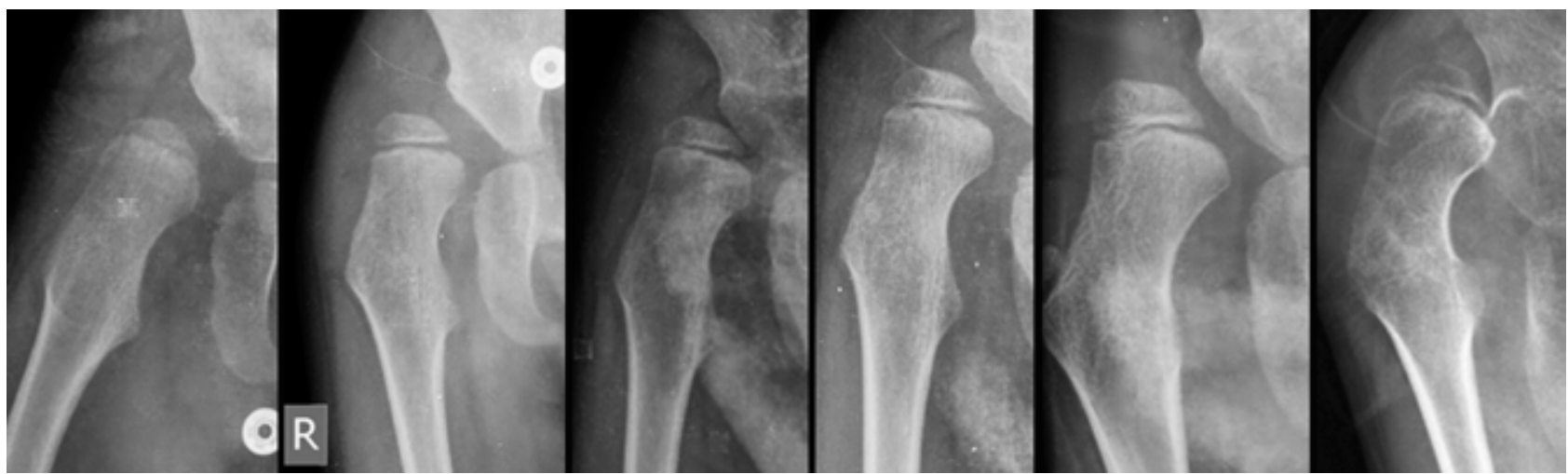

Şekil 7. Migrasyon indeksinde artma sonrası tedaviyi kabul etmeyen hastada 3,5 yıl sonra kalçanın çıkık haline gelmesi.

abduksiyonunun $45^{\circ}$ 'nin altına düştüğü ve Mi'nin \%25'in üzerine çıktığı olgularda, hastalar daha sık izlenmeli ve Mi artışları devam ederse gerekli yaklaşımlarla tedavi edilmelidir.

\section{SP'Li HASTADA KALÇAYA YAKLAŞIM}

SP'li hastalarda tutulumun tipi paralitik kalça çıkığı ile karşılaşılmasında en etkili etken gibi durmaktadır. Hiç yürümemiş spastik kuadriparetik hastalar en riskli gruptur. Hemiplejik ve ataksik gruplarda neredeyse hiç kalça çıkığı sorunu yaşanmaz. SP'li hastalarda kalça sorunları en sık 2-6 yaş arasında görülür.

Polikliniğe ilk kez başvuran, yürümeyen, spastik kuadriparetik, mental retardasyonun ağır olduğu, skolyoz veya pelvik oblikliği olan hastaların mutlaka ön-arka planda kalça grafisi çekilmeli ve Mi değerlendirilmelidir.
İskandinav ülkelerinde SP'li hastaları değerlendirmek için bir program geliştirilmiştir. Hastaların yaş ve kaba motor fonksiyon sınıflandırma sistemi (GMFCS) seviyelerine göre değerlendirme yapılmaktadır (Tablo 1 ).

GMFCS-I hastalarda kalça grafisine ihtiyaç yoktur. Sadece 2-6 yaşa arası GMFCS-II hastalarda kalça grafisi gereklidir. Fizik muayene kötüleşmezse ve Mi \%33'ün altındaysa grafi gerekli değildir. GMFCS-III ve IV hastalarda; sekiz yaşa kadar yıllık kalça grafisi kontrolü yapılmalıdır. GMFCS-IV ve $V$ hastalar en ciddi risk altında olan hasta grubudur. Özellikle 2-6 yaş arası sıkı izlem (3-6 ay arayla) yapılmalıdır.

Mi'nin \%33-40 arasında olduğu kalçalar risk altındadır. Kalça abduksiyon hareket açıklığında azalma olursa ve Mi progresif olarak artarsa önleyici girişimler yapılabilir. Fakat Mi \%40'ın üstüne çıkarsa, paralitik çıkık olmasın diye cerrahi tedavi planlanmalıdır.

Tablo 1. Kaba motor fonksiyon sınıflandırma sistemi (GMFCS). ${ }^{[11]}$

\begin{tabular}{cl}
\hline Seviye & Motor fonksiyon \\
\hline I & $\begin{array}{l}\text { Ev içi ve ev dışında herhangi bir sınırlama olmadan yürüyebilir, merdiven çıkabilir, koşabilir ve sıçrayabilir; fakat denge ve } \\
\text { koordinasyon bozuktur. }\end{array}$ \\
II $\quad$ Ev içi ve ev dışında yürüyebilir, tırabzanlara tutunarak merdiven çıkabilir; fakat düzgün olmayan ve eğimli yüzeylerde, \\
kalabalıkta ve uzun mesafe yürürken zorlanır. \\
III $\quad \begin{array}{l}\text { Ev içi ve ev dışında düz bir yüzeyde yardımcı cihazla yürür, tırabzanlara tutunarak merdiven çıkabilir; fakat uzun mesafelerde ve } \\
\text { düzgün olmayan yüzeylerde tekerlekli sandalye kullanır. }\end{array}$ \\
Kısa mesafe yürüyüşte yürüteç ile yürüyebilir ve genelde bir yetişkinin yardımına ihtiyaç duyar; evde, okulda ve toplum içinde \\
tekerlekli sandalye ile hareket eder. \\
V $\quad \begin{array}{l}\text { Yerçekimine karşı baş ve gövde duruşunu dengeleyemez ve istemli hareket kontrolü zayıftır; tüm bölgelerin motor kontrolü } \\
\text { zayıftır; bağımsı hareketi yoktur ve bir yetişkinin yardımı ile taşınır. }\end{array}$
\end{tabular}




\section{SP'Li KALÇALARDA TEDAVI YAKLAŞIMI VE YÖNTEMLERI}

SP'li hastalarda asıl önemli olan çıkmış kalçanın tedavisi değil, kalçanın çıkmasının önlenmesidir. Bu yüzden de hastanın ve ailesinin fizik tedaviye uyumu, hastanın belli aralıklarla düzenli değerlendirilmesi ve multidisipliner bir yaklaşımın uygulanması gerekir. Fizik tedavide özellikle hastanın doğru pozisyonda tutulması, kaslarının güçlendirilmesi, antagonist kaslar arası dengenin sağlanması, gergin kaslarının gevşetilmesi, hastanın cihazlanması ve eklem hareket açıklıklarının korunmaya çalışııması oldukça önemlidir. Bu rehabilitasyon uygulamaları, bilinçli ve uyumlu aile, mental açıdan iyi tedaviye olabildiğince direnç göstermeyen hafif tutulumlu hasta ve dönemik aralıklarla yapılan ortopedik kontroller ve radyolojik değerlendirmeler kalça çıkığı oluşmasını engelleyen en önemli etkenlerdir.

SP'li hastanın kalça sorunlarında temel amaç; kalçanın konsantrik redüksiyonunun sağlanması, varsa ağrısının giderilmesi, hastanın oturma dengesinin ve perineal hijyenin sağlanmasıdır.

\section{SP'ye Bağlı Kalça Sorunlarında Uygulanan Tedavi Yöntemleri}

1. Yumuşak doku gevşetmeleri

2. Kemik ameliyatları (femoral veya asetabular)

3. Kurtarıcı ameliyatlar

\section{Yumuşak Doku Ameliyatları}

Yumuşak doku ameliyatı, adduksiyon kontraktürünün ilerleyici olduğu olgularda beklenmeden yapılmalıdır. İskandinav çalışma grubu Mi \%33-40 arası izlemi önerirken, GMFCS-II ve üstü hastalarda Mi \%40'ın üzerinde ise, hastalara yumuşak doku gevşetme ameliyatlarını önermektedir. ${ }^{[12]}$ Miller ve ark. ise sekiz yaş altı, kalça abduksiyon açıklığı $30^{\circ}$ 'nin altında ve Mi \%25-60 arası olan çocukların yumuşak doku ameliyatından yarar gördüklerini bildirmişlerdir. ${ }^{[13]}$

\section{Cerrahi teknik}

Yumuşak doku gevşetme ameliyatında ilk olarak adduktor longus tendonu kesilir. Eğer kalça abduksiyonu $45^{\circ}$ ye çıkmazsa adduktor brevis kası da kesilmelidir. Eskiden yumuşak doku gevşetmelerine sık olarak obturator nörektomi ameliyatı eklenirdi. Son yıllarda abduksiyon kontraktürü geliştirdiğinden dolayı, bu ameliyat instabiliteye ve fibrozise neden olduğundan kesinlikle önerilmemektedir. Yürümeyen hastalarda, aynı kesiden iliopsoas tendonu da trokanter minora yapışma yerinden kesilir. Eğer hasta yürüyorsa, psoas kası pelvik halka üzerinden ayrı bir kesi ile uzatılmalıdır. Eskiden rutin alçı veya cihaz uygulanırdı. Son dönemlerde bunun yerine en yakın dönemde rehabilitasyona başlanması önerilmektedir. Girişim başarılı ise, kalça ön-arka grafilerinde Mi'de azalma gözlenmelidir. Bu amaçla hastaların altı ay aralıklarla kalça grafisi çekilmelidir.

\section{Kemik Ameliyatları}

Yumuşak doku ameliyatlarına ek olarak; femoral, asetabular veya ikisi birlikte kemik ameliyatları yapılabilir. Kemik ameliyatlarına karar vermede en önemli belirteçler hastanın yaşı ve luksasyonun derecesidir. Miller ve ark., çocuğun kalçasında spastisite ya da kontraktür yoksa, dört yaş üzerinde ve Mi \%60'ın üzerinde ise, yani kalçada subluksasyon varsa kemik ameliyatlarının gerekli olduğunu bildirmişlerdir. ${ }^{[13]}$

Dört yaş üzeri ve $\mathrm{Mi}>\% 60$, sekiz yaş altı yumuşak doku gevşetmesine rağmen son bir yılda $\mathrm{Mi}>\% 40$ seyrediyorsa, sekiz yaş üstü $\mathrm{Mi}>\% 40$ ise ve kalça ekleminde dejeneratif değişiklikler yoksa, kemik ameliyatları yapılabilir.

\section{Femur proksimal osteotomisi}

Femura kısaltma, varizasyon ve derotasyon uygulanır. Özellikle yürümeyen hastalarda femur boyuncisim açısı oldukça artmıştır. Kimi olgularda neredeyse $180^{\circ}$ kadardır. Kalça eklemine açık redüksiyon yaparak veya yapmadan femura kısaltma ile birlikte varizasyon ve gerekli olgularda derotasyon yapılmalıdır. Yürümeyen olgularda femur boyun-cisim açısı $100^{\circ}$, yürüyen hastalarda $120^{\circ}$ 'ye getirilmelidir. Sekiz yaşın üstünde femur proksimal bölgesine yapılan osteotomilerin yeniden şekillenme potansiyeli ile bir miktar düzeleceği akılda tutulmalıdır. Ancak, 4-8 yaş arası yapılan osteotomilerde bu risk daha da fazladır. Artmış femoral anterversiyon açısı, serebral palsili hastalarda en temel sorunlardan biridir. Hem yürürken dizlerin birbirine çarpmasına neden olarak yürümeyi zorlaştırmakta hem de adduksiyon kontraktürüne görece katkı sağlamaktadır. Femur proksimal bölgesine varizasyon yapılan tüm hastalara neredeyse $40-60^{\circ}$ 'lerde derotasyon yapılmalıdır (Şekil 8). Böylece özellikle yürüyen çocuklarda yürüyüş paterni düzelmekte ve yapılan derotasyon varizasyon miktarını da azaltmaktadır.

\section{Asetabular osteotomi}

Dega, Modifiye San Diego veya Tönnis osteotomileri yapılmaktadır. ${ }^{[14-16]}$ En tercih edileni Dega osteotomisidir. ${ }^{[17]}$ Çünkü paralitik kalçalarda GKD'den farklı olarak kas kontraktürlerine bağlı olarak ikincil posterior asetabular yetmezlik gelişmektedir. Sublukse olgularda sadece femoral osteotomi ile kalça konsantrik redüksiyonu sağlanabilirken (Şekil 9), başarılı olunamayan 


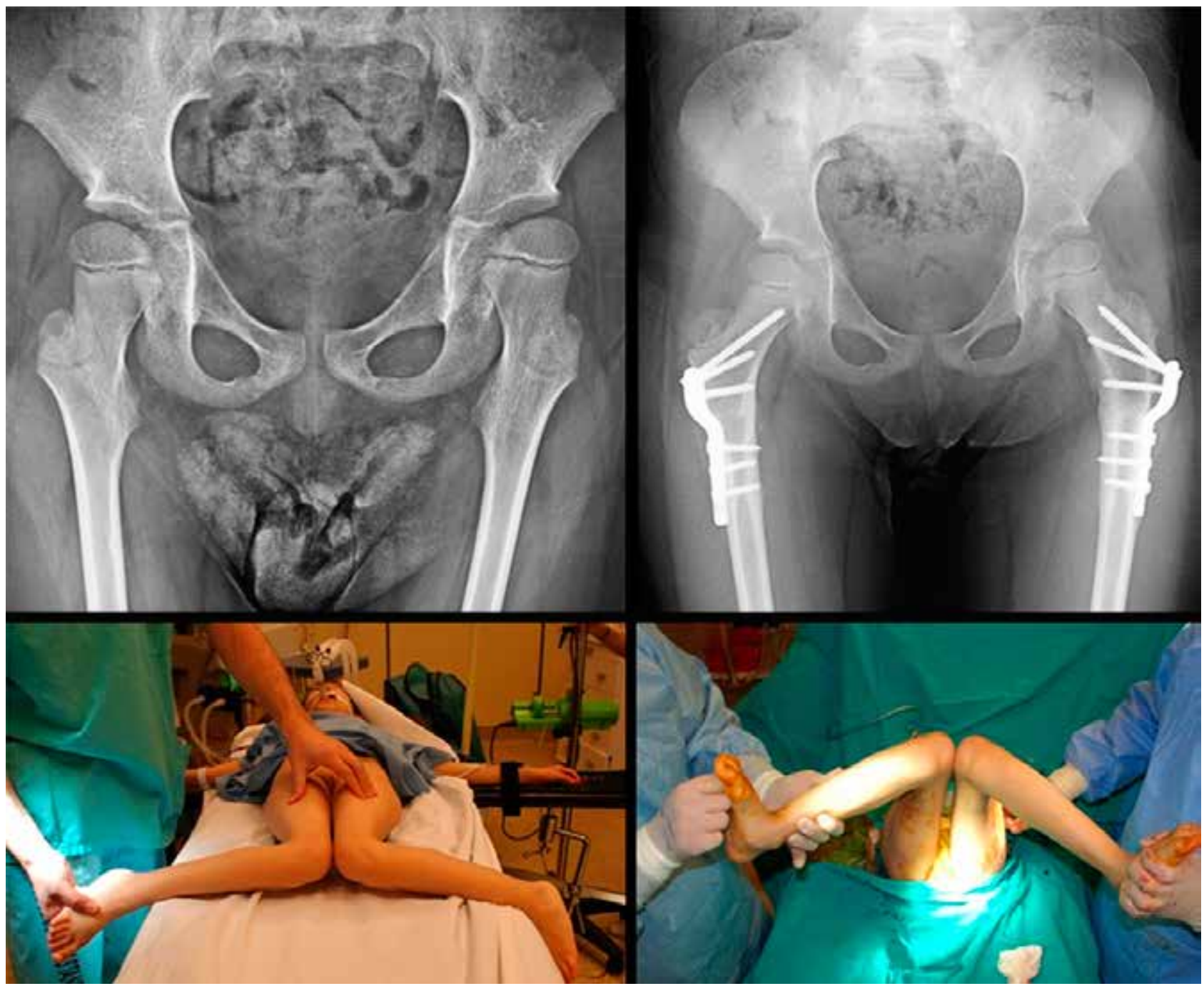

Şekil 8. Artmış femoral anteversiyon ve iki taraflı femurdan VDRO sonrası klinik ve radyolojik görünüm.
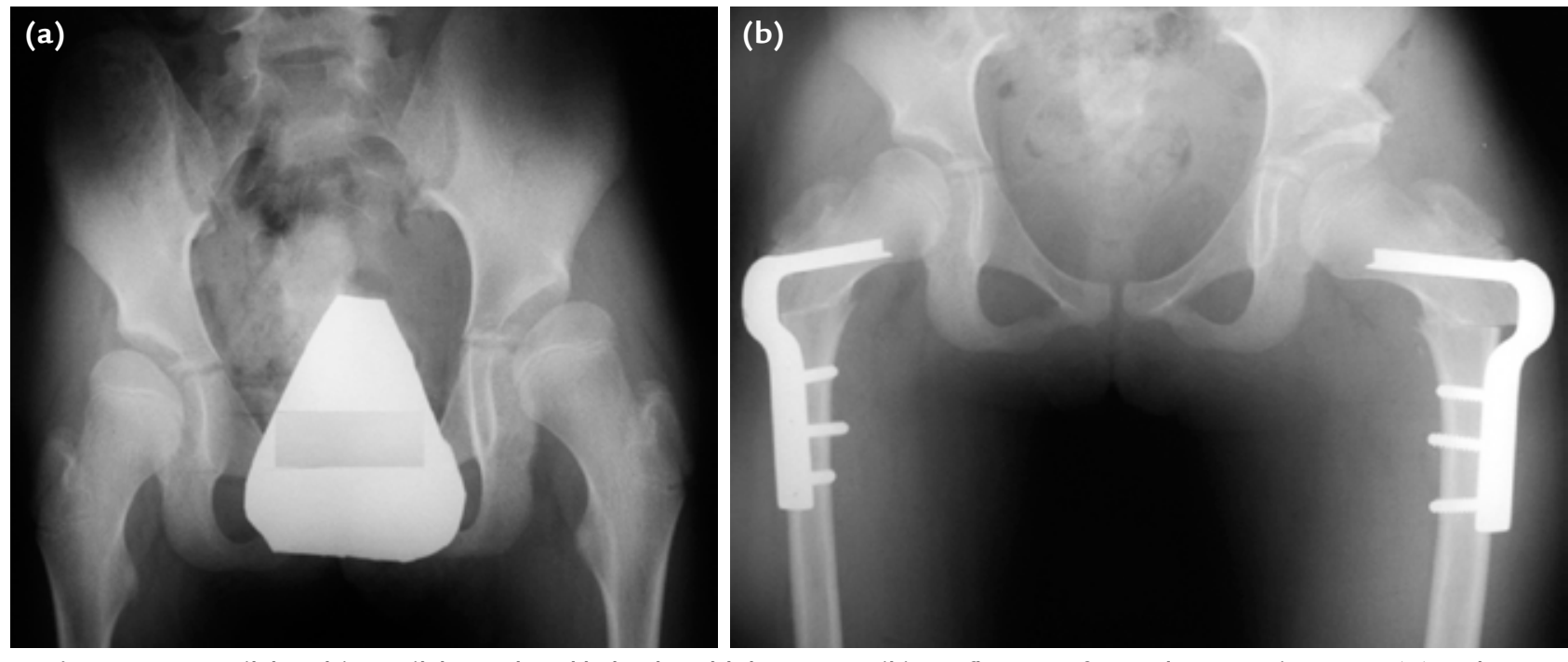

Şekil 9. a, b. Spastik kuadriparetik hastada sol kalçada subluksasyon ve iki taraflı artmış femoral anteversiyon açısı (a). Sola Dega osteotomisi ve iki taraflı femur proksimaline varizasyon derotasyon osteotomisi (VDRO) (b). 

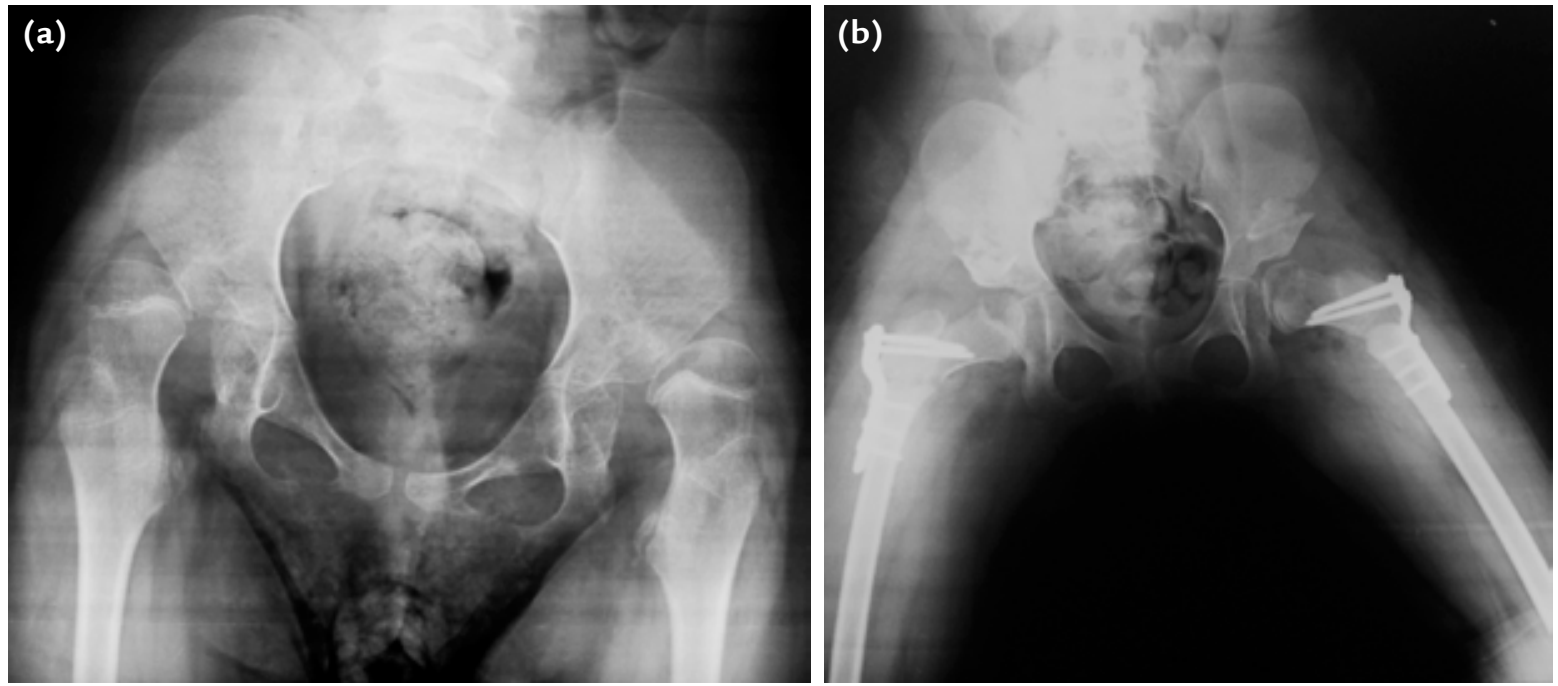

Şekil 10. a, b. İki taraflı paralitik kalça çıkıklı spastik kuadriparetik hasta (a). Aynı anda iki taraflı Dega osteotomisi ve VDRO sonrası hastanın ameliyat sonrası grafisi (b).
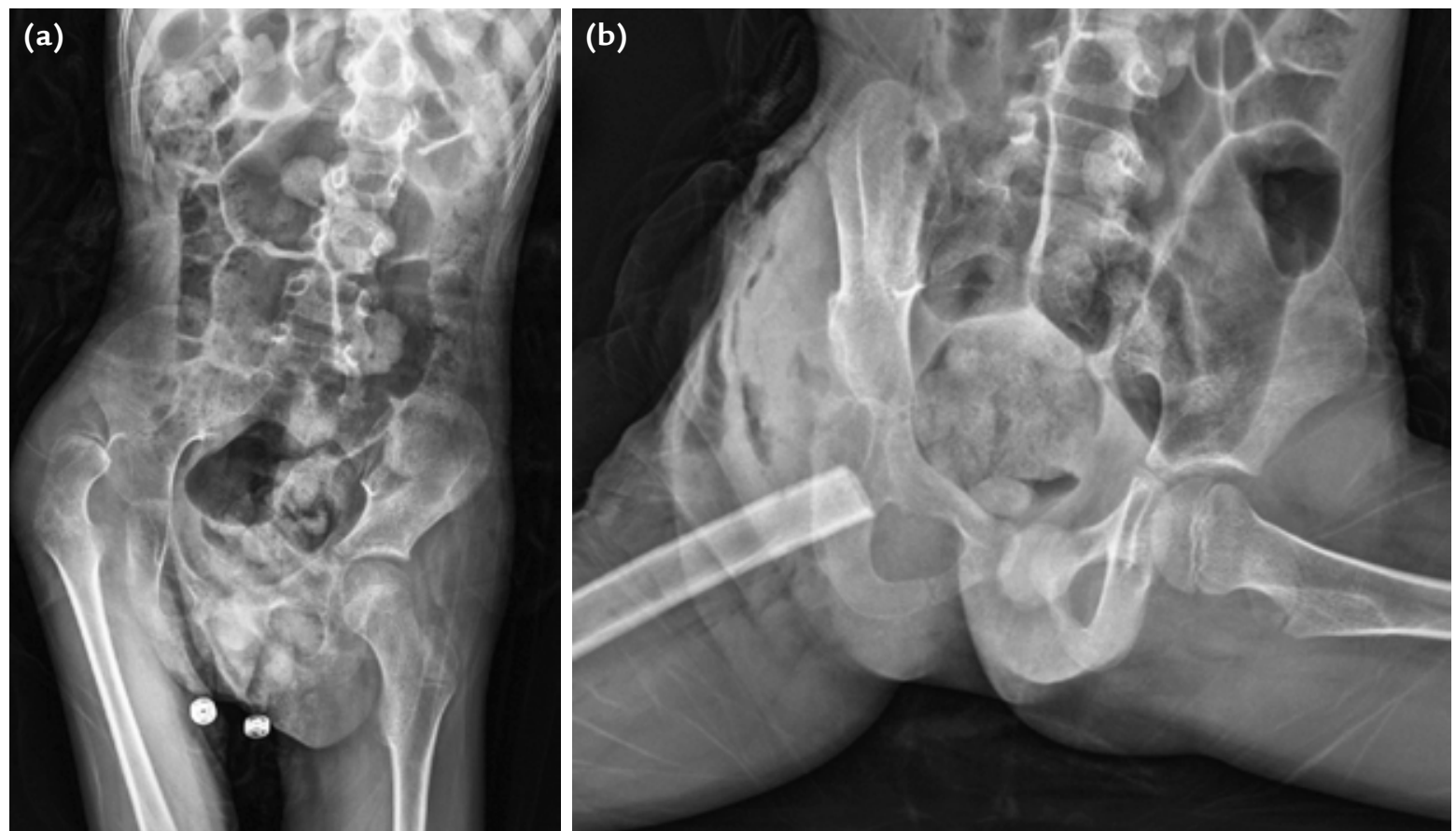

Şekil 11. a, b. Spastik kuadriparetik yürüme potansiyeli olmayan 15 yaşında hastada pelvik oblik-lik ve kalça çıkı̆̆ı (a). Aynı hastanın femur baş-boyun rezeksiyonu sonrası görünümü (b).

veya çıkık olgularında bu asetabular osteotomilerle kombine edilmelidir (Şekil 10). Cerrahi sonrası pelvipedal alçılama uygulanır. Alçı 30-45 gün sonrası çıkarılarak, egzersiz ve kaynamanın derecesine göre kısmi veya tam yüklenmeye geçilir.

Kalçada subluksasyon veya çıkık varsa ve yumuşak doku gevşetmeleri ile başarılı olunamadıysa veya başarılı olunamayacağı düşünülüyorsa, tüm cerrahi tedavi tek aşamada yapılmalıdır. Bu şekilde de oldukça başarılı sonuçlar bildirilmektedir. ${ }^{[15,18]}$

Çok gecikmiş ve ağrılı olgularda proksimal femurvalgus osteotomisi veya proksimal femur rezeksiyon ameliyatları uygulanabilir (Şekil 11). Bunlar oldukça invaziv ve büyük ameliyatlardır. 
Sonuç olarak; serebral palside kalça sorunları, kas kontraksiyonlarına bağlı, sonradan oluşan, önlenebilir, oluştuğu zaman da büyük cerrahi girişimlere neden olan bir durumdur.

\section{KAYNAKLAR}

1. Barbera OF, Navarro IS. Gross anatomy. In: Thomas Byrd JW, editor. Operative Hip Arthroscopy, 2nd ed. New York: Springer-Verlag; 2013. pp.85-97. Crossref

2. Moore KL, Agur AMR, Dalley AF. Clinically Oriented Anatomy, 7th ed. Baltimore: Lippincott Williams and Wilkins; 2014. 1168p.

3. Neumann DA. Kinesiology of the Musculoskeletal System: Foundations for Physical Rehabilitation, 2nd ed. St Louis, Mo: Mosby; 2010. pp.387-433.

4. Hamill J, Knutzen KM. Biomechanical Basis of Human Movement, 3rd ed. Baltimore: Lippincott Williams \& Wilkins; 2009. pp.187-254.

5. Turgut A. Kalça eklemi anatomisi ve biyomekaniği. TOTBiD Derg 2015;14(1):27-33. Crossref

6. Flynn JM, Miller F. Management of hip disorders in patients with cerebral palsy. J Am Acad Orthop Surg 2002;10(3):198209. Crossref

7. Hägglund $G$, Andersson S, Düppe $H$, Lauge-Pedersen $H$, Nordmark E, Westbom L. Prevention of dislocation of the hip in children with cerebral palsy. J Bone Joint Surg Br 2005;87$B(1): 95-101$. Crossref

8. Scrutton D. The early management of hips in cerebral palsy. Dev Med Child Neurol 1989;31(1):108-16. Crossref

9. Kalenderer Ö, Erkuş S. Çocuklarda alt ekstremitenin nörolojik muayenesi. İçinde: Kalenderer Ö, editör. Çocuklarda Ortopedi Muayenesi. Ankara: Karınca Creative Ajans, Eflal Matbaacılık; 2017. s.65-74.
10. Cooke PH, Cole WG, Carey RP. Dislocation of the hip in cerebral palsy. Natural history and predictability. J Bone Joint Surg Br 1989;71-B(3):441-6. Crossref

11. McHale KA, Bagg M, Nason SS. Treatment of the chronically dislocated hip in adolescents with cerebral palsy with femoral head resection and subtrochanteric valgus osteotomy. J Pediatr Orthop 1990;10(4):504-9. Crossref

12. Larnert $P$, Risto $O$, Hägglund $G$, Wagner $P$. Hip displacement in relation to age and gross motor function in children with cerebral palsy. J Child Orthop 2014;8(2):129-34. Crossref

13. Miller F, Cardoso Dias R, Dabney KW, Lipton GE, Triana M. Soft-tissue release for spastic hip subluxation in cerebral palsy. J Pediatr Orthop 1997;17(5):571-84. Crossref

14. Józwiak M, Marciniak W, Piontek T, Pietrzak S. Dega's transiliac osteotomy in the treatment of spastic hip subluxation and dislocation in cerebral palsy. J Pediatr Orthop B 2000;9(4):257-64. Crossref

15. Mubarak SJ, Valencia FG, Wenger DR. One-stage correction of the spastic dislocated hip. Use of pericapsular acetabuloplasty to improve coverage. J Bone Joint Surg Am 1992;74(9):1347-57. Crossref

16. Tönnis $D$, Briining $K$, Heinecke A. Lateral asetabular osteotomy. J Pediatr Orthop B 1994;3(1):40-6. Crossref

17. Miller F, Girardi H, Lipton G, Ponzio R, Klaumann M, Dabney KW. Reconstruction of the dysplastic spastic hip with periilial pelvic and femoral osteotomy followed by immediate mobilization. J Pediatr Orthop 1997;17(5):592-602. Crossref

18. Oto M, Sarıkaya IA, Erdal OA, Şeker A. Surgical reconstruction of hip subluxation and dislocation in children with cerebral palsy. Eklem Hast Cerrahisi 2018;29(1):8-12. Crossref 